\title{
Standardization and utilization of Himalayan nettle (Girardinia diversifolia) roots for the dyeing of silk fabric
}

\author{
Bhandari, B. ${ }^{1} \bowtie$ and Rani A. ${ }^{2}$
}

Received: 05.12.2020

Revised: 30.01.2021

Accepted: 16.03.2021

\section{Abstract}

The nature is abode to numerous plants, animal and mineral resources that offersustainable alternative to chemicalsused in textile dyeing. In this paper an effort has been made to utilize the roots of Himalayan nettle plant for fabric dyeing which grows abundantly in-the higher altitude of Uttarakhand as a weed plant. The extraction and dyeing variables were optimized for application on silk fabric on the basis of colour strength and wash fastness rating. Dye extraction carried out in aqueous medium at simmering temperature for 1.5 hoursresulted in better colour depth and washing fastness. Similarly, dyeing of silk at $90^{\circ} \mathrm{C}$ for 90 minutes using $3 \mathrm{gm}$ per $100 \mathrm{ml}$ powdered dye material yielded better dyed samples in terms of colour strength and wash fastness. The obtained dye recipe is easy to be used by dyeing units at minimal cost since no chemicals are added during dyeing and raw material can be collected from pastures, around croplands and nearby forest areas.

Key words: Himalayan Nettle, Textile Dye, Dye Recipe, Silk Dyeing

\section{Introduction}

Natural dyes are obtained from renewable sources and are biodegradable. Their use reduces the overall carbon footprint by reducing the fossil fuel consumption. Now people have started giving importance to using green products in everyday life with increasing awareness of eco-safety and health issues. With regard to the beneficial aspects of natural dyes, the need was realized to revive the dying art of natural dyeing practiced by craftsmen engaged in traditional arts and crafts around the world. Since ancient times natural dyes extracted from plant sources have been known to mankind. Colours obtained from these natural dyes are specialty colours which signify the age-old heritage of Indian dyed textile industry. In ancient times, superior quality of natural dyes were imported for dyeing apparels of the upper class and ruling people. These were traded along with agricultural commodities which helped in enhancing economic status of countries (Ammayappan, 2009). Use of natural dyes at small scale doesn't pose any environmental hazard however extraction of natural Author's Address

${ }^{1}$ Dept of Textile Design, NIFT Kangra, Himanchal Pradesh

${ }^{2}$ Department of Clothing and Textiles, College of Home Science, G. B. P. U. A. and T., Pantnagar

E-mail.: babita.bhandari@nift.ac.in dyes from plant sources on a large scale would cause biodiversity loss. Factors like seasonal production and production in limited quantities of natural dyes have challenged mankind to explore various other sources of natural dyes. Hence researchers are focusing on extracting dyes from natural resources that are otherwise undesirable in nature or their use has not been established much. It presents a huge scope for investigating into dyeing capability of plants which are abundantly available in nature. The abundant vegetative sources found in nature if used as source for dye can be sustainable option in terms of environment, economic and social viability particularly in a hill state like Uttarakhand where people are migrating from rural to urban areas in search of employment. One such resource is Himalayan nettle plant which grows undesirably alongside the croplands. Its stem is commonly used for extracting fibers but its usage as dye material has not been recognized yet. Himalayan nettlei.e. Girardinia diversifolia commonly grows in higher -altitude states like Uttarakhand, Jammu and Kashmir, Himanchal Pradesh as well as in parts of Nepal and China. This plant is a perennial which can grow tall and stout under shade and damp areas upto 3 meters. Moreover it can grow in diverse habitats like 
savanna, open forest, cultivated areas, dry forest, rain forest, moist rocky areas within the altitude of 500 to 2600 meters. The stem of the experimental plant are widely used for extracting strong and smooth fibres which are used for creating many articles of daily use (Misraet al., 2010). Local artisans in communities of Himalayan region used the root part of the plant to colour handicrafts and apparels having low colour fastness properties (Kumar et al., 2015).

Therefore, an effort has been made to dye the silk fabric using the crude extract obtained from root part of Himalayan nettle. The objective of this research is to standardized the extraction and dye parameters for the dyeing of silk fabric. The application of the obtained standardized recipe shall reduce the consumption of chemicals, energy, dye material as well as time.

\section{Materials and Methods}

The off white coloured silk fabric was purchased from Gandhi Ashram retail shop of Pantnagar (Uttarakhand) at the cost of Rs 500 per meter. Degumming of silk fabric was done to prepare it for dyeing. Collection of roots of $G$. diversifolia found in and around crop lands was carried out from Pithoragarh district of Uttarakhand as shown in Fig 1 . The roots were properly cleaned to get rid of soil and were dried at room temperature under shade for one week and then oven dried for 24 hours at $50^{\circ} \mathrm{C}$ as shown in Fig 2. The properly dried roots were ground into powder form using grinder. The dye powder was kept in tightly closed containers at room temperature for further study. To optimize the extraction medium, extraction was carried using $2 \mathrm{gm}$ of dye material in $100 \mathrm{ml}$ distilled water at $90^{\circ} \mathrm{C}$ for 60 minutes at acidic, neutral and alkaline medium. Silk sample of $1 \mathrm{gm}$ was dyed at $80^{\circ} \mathrm{C}$ of dyeing temperature for 60 minutes. After dyeing the sample was removed from dye bath, allowed to cool, rinsed under running tap water and squeezed lightly. The dyed sample was then assessed for colour strength and wash fastness. The colour strength of dyed sample was measured using a computer aided dual spectrophotometer Premier colour scan 5100A. The software automatically generates the colour strength value i.e. K/S using the reflectance of the coloured sample. Wash fastness was determined as per the recommendations of IS: 3361-1979 method (BIS, 1979) which was carried out at $50^{\circ} \mathrm{C}$ for 45 minutes without using steel balls and sodium carbonate in the launder-o-meter. The extraction medium that yielded maximum colour strength and wash fastness on dyed fabric samples was selected as optimum medium of extraction. Similarly optimization of other variables namely extraction temperature and extraction time and dye concentration, dyeing temperature and dyeing time was carried out by varying the parameters as given in Table 1.

Table 1: Range of the dyeing variables used in the study.

\begin{tabular}{|c|c|}
\hline Variables & Range \\
\hline Extraction medium & alkaline, acidic and neutral \\
\hline Extraction temperature & $\begin{array}{lll}50^{\circ} \mathrm{C}, \quad 60^{\circ} \mathrm{C}, & 70^{\circ} \mathrm{C}, \quad 80^{\circ} \mathrm{C} \\
\text { and } 90^{\circ} \mathrm{C}\end{array}$ \\
\hline Extraction time & 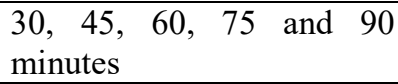 \\
\hline $\begin{array}{l}\text { Concentration of dye } \\
\text { material }\end{array}$ & $1,2,3,4$ and $5 \mathrm{~g}$ \\
\hline Dyeing temperature & $\begin{array}{l}50^{\circ} \mathrm{C}, \quad 60^{\circ} \mathrm{C}, \quad 70^{\circ} \mathrm{C}, \quad 80^{\circ} \mathrm{C} \\
\text { and } 90^{\circ} \mathrm{C}\end{array}$ \\
\hline Dyein & 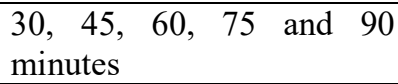 \\
\hline
\end{tabular}

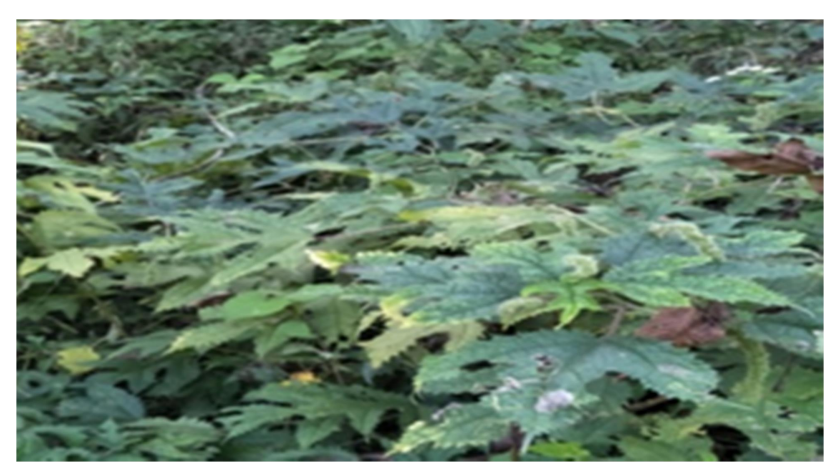

Figure 1. Plant of Himalayan nettle

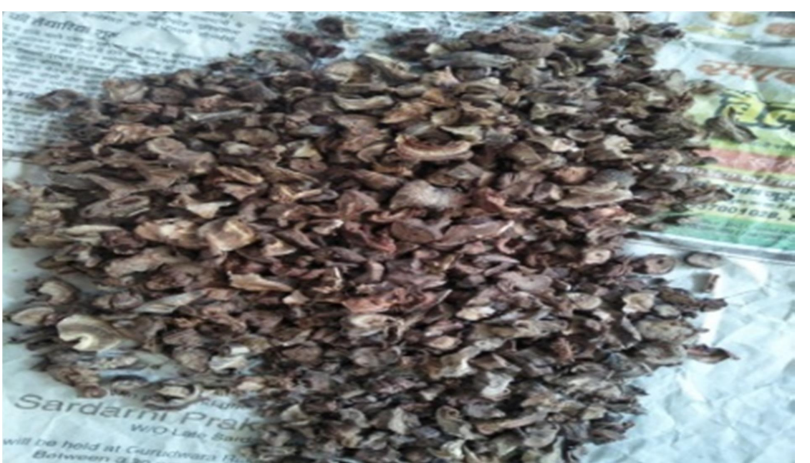

Fig 2. Dried root crumbs of Himalayan nettle 


\section{Results and Discussion}

The results of colour strength and wash fastness for different extraction and dyeing parameters were presented in Table 2 to Table7. Table 2 shows the colour strength and washing fastness of silk fabric samples dyed with $G$. diversifolia extracts which were extracted in different medias i.e., acidic, neutral and alkaline medium, respectivelyat $90^{\circ} \mathrm{C}$ for 60 minutes and dyed at $80^{\circ} \mathrm{C}$ for 60 minutes.

It is evident from the data in Table 2 that the highest colour strength was displayed by silk samples which was dyed using dye extracted in acidic medium at pH 5 i.e., 5.23 and lowest colour strength $(\mathrm{K} / \mathrm{S})$ was exhibited by sample dyed in alkaline medium. However, no significant difference was observed in colour strength of dyed silk fabric samples when dye was extracted in acidic and neutral medium.Vidhya and Gowda, 2017 also quoted that $\mathrm{pH}$ value can significantly affect the dyeability of silk fabric. With the increase in $\mathrm{pH}$, a reduction in dye ability of silk was observed. Bird, 1989 and Gulrajani, 1993 stated that dye absorption in neutral conditions might be due to the presence of hydrocarbon chain of silk

Table 2: Colour properties of silk dyed with $G$. diversifolia extracted at different medium

\begin{tabular}{|c|c|c|c|c|}
\hline \multirow{2}{*}{ SN } & \multirow{2}{*}{ Extraction medium } & \multirow{2}{*}{ Colour strength (K/S) } & \multicolumn{2}{|c|}{ Wash fastness } \\
\cline { 3 - 5 } & & & CC & CS \\
\hline 1 & Acidic & $5.23 \pm 0.13^{\mathrm{b}}$ & $3-4$ & 4 \\
\hline 2 & Neutral* & $5.14 \pm 0.13^{\mathrm{b}}$ & 4 & $4-5$ \\
\hline 3 & Alkaline & $4.37 \pm 0.13^{\mathrm{a}}$ & 3 & $3-4$ \\
\hline
\end{tabular}

CC: Colour change, CS: Colour staining; ${ }^{*}$ Selected medium

Data followed by same letter had no significant difference according to Tukey post hoc test $(\mathrm{p}<0.05)$ at $5 \%$ level of significance

Table 3: Colour properties of silk dyed with $G$. diversifolia extracted at different temperature

\begin{tabular}{|c|c|c|c|c|}
\hline \multirow{2}{*}{ SN } & \multirow{2}{*}{$\begin{array}{c}\text { Extraction temperature } \\
\left({ }^{\mathbf{o}} \mathbf{C}\right)\end{array}$} & \multirow{2}{*}{ Colour strength $(\mathbf{K} / \mathbf{S})$} & \multicolumn{2}{|c|}{ Wash fastness } \\
\cline { 3 - 5 } & & & CC & CS \\
\hline 1 & 60 & $1.70 \pm 0.14^{\mathrm{a}}$ & $1-2$ & $2-3$ \\
\hline 2 & 70 & $1.91 \pm 0.14^{\mathrm{a}}$ & $2-3$ & $2-3$ \\
\hline 3 & 80 & $2.56 \pm 0.14^{\mathrm{b}}$ & 3 & 3 \\
\hline 4 & 90 & $3.46 \pm 0.14^{\mathrm{c}}$ & 3 & $3-4$ \\
\hline 5 & $100^{*}$ & $4.52 \pm 0.14^{\mathrm{c}}$ & 4 & 4 \\
\hline
\end{tabular}

Data followed by same letter have no significant difference according to Tukey post hoc test ( $\mathrm{p}<0.05)$ at $5 \%$ level of significance; CC: Colour change, CS: Colour staining; $*$ Selected temperature

Table 4: Colour properties of silk dyed with $G$. diversifolia extracted for different time durations

\begin{tabular}{|c|c|c|c|c|}
\hline \multirow{2}{*}{ SN } & \multirow{2}{*}{$\begin{array}{c}\text { Extractiontime } \\
\text { (minutes) }\end{array}$} & Colour strength $(\mathbf{K} / \mathbf{S})$ & \multicolumn{2}{|c|}{ Silk fabric } \\
\cline { 3 - 5 } & & & \multicolumn{2}{|c|}{ WCash fastness } \\
\hline 1 & 30 & $2.34 \pm 0.15^{\mathrm{a}}$ & $1-2$ & $2-3$ \\
\hline 2 & 45 & $2.70 \pm 0.15^{\mathrm{a}}$ & $2-3$ & 3 \\
\hline 3 & 60 & $3.70 \pm 0.15^{\mathrm{b}}$ & 3 & $3-4$ \\
\hline 4 & 75 & $4.46 \pm 0.15^{\mathrm{c}}$ & 3 & $4-5$ \\
\hline 5 & $90^{*}$ & $4.98 \pm 0.15^{\mathrm{d}}$ & 4 & 3 \\
\hline
\end{tabular}

CC: Colour change, CS: Colour staining; * Selected time

Data followed by same letter have no significant difference according to Tukey post hoc test $(\mathrm{p}<0.05)$ at $5 \%$ level of significance 


\section{Bhandari and Rani}

that was having hydrophobic regions and leads to the applications of acid dye on protein fiber. Wash fastness results revealed that better rate was obtained when dye was extracted in neutral medium and used for dyeing silk fabric samples. Based upon the results, neutral medium was selected for further dye extraction for dyeing silk fabric samples. Mukherjee and Karajan, 2017 also selected the neutral $\mathrm{pH}$ as optimum $\mathrm{pH}$ for extracting dye from Cosmos sulphureus for silk yarn dyeing. Table 3 depicts the colour strength and wash fastness of silk fabric samples dyed with dye extracted at five different temperature levels. The extraction temperature determines the solubility of dye particles in water; higher the extraction temperature, more the colour gets extracted from the dye particles. In case of silk samples, maximum colour strength was observed at $100^{\circ} \mathrm{C}$ of extraction temperature. Bouzidi et al., 2011 also found that colour strength increased with increasing dye extraction temperature, reaches highest at $90^{\circ} \mathrm{C}$. Wash fastness grades show the similar trend and the fastness ranged from fair (2) to very good (4) rating of fastness.

Table 5: Colour properties of silk dyed withdifferent concentration of $G$. diversifolia

\begin{tabular}{|c|c|c|c|c|}
\hline \multirow{2}{*}{ SN } & \multirow{2}{*}{$\begin{array}{c}\text { Dye concentration }(\mathbf{g} / \mathbf{1 0 0} \\
\mathbf{m l})\end{array}$} & \multicolumn{2}{|c|}{ Silk fabric } \\
\cline { 3 - 5 } & 1 & $\begin{array}{c}\text { Wolour strength } \\
(\mathbf{K} / \mathbf{S})\end{array}$ & $\mathbf{C C}$ & CS \\
\hline 1 & 2 & $3.26 \pm 0.12^{\mathrm{a}}$ & 4 & $4-5$ \\
\hline 2 & $3^{*}$ & $3.44 \pm 0.15^{\mathrm{ab}}$ & 4 & $4-5$ \\
\hline 3 & 4 & $3.53 \pm 0.15^{\mathrm{abc}}$ & 4 & $4-5$ \\
\hline 4 & 5 & $3.65 \pm 0.15^{\mathrm{bc}}$ & 4 & $4-5$ \\
\hline 5 & 2 & $3.83 \pm 0.15^{\mathrm{c}}$ & $3-4$ & 4 \\
\hline
\end{tabular}

CC: Colour change, CS: Colour staining; * Selected levels

Data followed by same letter have no significant difference according to Tukey post hoc test $(\mathrm{p}<0.05)$ at $5 \%$ level of significance

Table 6: Colour properties of silk dyed with $G$. diversifoliaat different dyeing temperature

\begin{tabular}{|c|c|c|c|c|}
\hline \multirow{2}{*}{ SN } & \multirow{2}{*}{$\begin{array}{c}\text { Dyeing temperature } \\
\left({ }^{\mathbf{o}} \mathbf{C}\right)\end{array}$} & \multicolumn{2}{|c|}{ Silk fabric } \\
\cline { 3 - 5 } & & $\begin{array}{c}\text { Colour strength } \\
(\mathbf{K} / \mathbf{S})\end{array}$ & $\mathbf{C C}$ & $\mathbf{C S}$ \\
\cline { 3 - 5 } & 50 & $3.34 \pm 0.07^{\mathrm{a}}$ & $2-3$ & 2 \\
\hline 2 & 60 & $3.52 \pm 0.07^{\text {ab }}$ & 3 & 3 \\
\hline 3 & 70 & $3.73 \pm 0.07^{\mathrm{b}}$ & 3 & 4 \\
\hline 4 & 80 & $4.17 \pm 0.07^{\mathrm{c}}$ & $3-4$ & 4 \\
\hline 5 & $90^{*}$ & $4.69 \pm 0.07^{\mathrm{d}}$ & 4 & 4 \\
\hline
\end{tabular}

CC: Colour change, CS: Colour staining; $*$ Selected levels

Data followed by same letter have no significant difference according to Tukey post hoc test $(\mathrm{p}<0.05)$ at $5 \%$ level of significance

Table 7: Colour properties of silk dyed with G. diversifolia at different dyeing time

\begin{tabular}{|c|c|c|c|c|}
\hline \multirow{3}{*}{$\mathbf{S N}$} & \multirow{3}{*}{$\begin{array}{l}\text { Dyeing time } \\
\text { (minutes) }\end{array}$} & \multicolumn{3}{|c|}{ Silk fabric } \\
\hline & & \multirow{2}{*}{$\begin{array}{c}\text { Colour strength } \\
(\mathrm{K} / \mathrm{S})\end{array}$} & \multicolumn{2}{|c|}{ Wash fastness } \\
\hline & & & $\mathbf{C C}$ & $\mathbf{C S}$ \\
\hline 1 & 30 & $3.30 \pm 0.06^{\mathrm{a}}$ & 3 & 3 \\
\hline 2 & 45 & $3.56 \pm 0.06^{b}$ & 3 & $3-4$ \\
\hline 3 & 60 & $4.40 \pm 0.06^{\mathrm{c}}$ & 3 & 3 \\
\hline 4 & 75 & $4.61 \pm 0.06^{\mathrm{cd}}$ & $3-4$ & 4 \\
\hline 5 & $90 *$ & $4.78 \pm 0.06^{\mathrm{d}}$ & 4 & 4 \\
\hline
\end{tabular}

CC: Colour change, CS: Colour staining; * Selected levels

Data followed by same letter have no significant difference according to Tukey post hoc test $(\mathrm{p}<0.05)$ at $5 \%$ level of significance 
Table 8: Colour obtained using optimized parameters

\begin{tabular}{|c|c|}
\hline Fabric & Colour obtained \\
\hline Undyed silk & \\
\hline Dyed silk & \\
\hline
\end{tabular}

After considering colour strength and wash fastness, the temperature of $100^{\circ} \mathrm{C}$ was selected for dye extraction of $G$. diversifolia root material. The colour strength was also found to be increasing with temperature increasefrom $50^{\circ} \mathrm{C}$ to $150^{\circ} \mathrm{C}$ by Farooq et al. (2013). Yusuf et al. (2107) also obtained optimum extraction temperature as $90^{\circ} \mathrm{C}$ for extracting dye from Rubia cordifolia roots.

Table 4 shows the colour strength and wash fastness of dyed silk fabric samples with dye extracted for five different time durations i.e. 30, 45, 60, 75 and 90 minutes. Data in Table 4exhibits that as the time for dye extraction was increased from 30 minutes to 90 minutes, colour strength of dyed fabric samples also increased gradually from 2.34 to 4.98 in silk fabric samples.Significant change in colour strength was observed at 60,75 and 90 minutes of extraction. Wash fastness of dyed silk also improved with increases in extraction time from 30 to 90 minutes. Hence 90 minutes of extraction time was selected to extract the dye.

Swamyet al., 2016 also found 90 minutes and $90^{\circ} \mathrm{C}$ as optimum temperature and time for dye extraction from fresh flowers of Plumeria rubra for dyeing of silk fabric. Nagia and Mohamedy (2006) stated that at higher dye extraction time, more dye was dissolved in water due to hydrolysis. The increase in contact time between dye and solvent resulted in dissolution of more dye. Dye concentration ranging from 1 to $5 \mathrm{~g}$ per $100 \mathrm{ml}$ was extracted at $100^{\circ} \mathrm{C}$ for 90 minutes due to the negligible color shade obtained below $1 \mathrm{~g}$ per $100 \mathrm{ml}$ water. It is evident from Table 5 that as the concentration was increased from $1 \mathrm{~g}$ to $5 \mathrm{~g}$, colour strength value was also increased. Considering the significant difference among samples dyed with different dye concentrations, $3 \mathrm{~g}$ was selected as optimum concentration that showing maximum fastness of slight colour change (4) and slight to no staining (45). Further increase in dye concentration had resulted in increase in $\mathrm{K} / \mathrm{S}$ but it was found nonsignificant statistically. Table 6 shows the colour strength and wash fastness rating of silk fabrics dyed at various temperatures from $50^{\circ} \mathrm{C}$ to $90^{\circ} \mathrm{C}$. It is clearly depicted in the Table 6 that as the dyeing temperature was increased, the colour strength also increased significantly. Wash fastness was fair at $50^{\circ} \mathrm{C}$ of dyeing temperature in the dyed fabric and with increase in dyeing temperature, fastness rating improved to be very good. Hence $90^{\circ} \mathrm{C}$ was selected as optimum dyeing temperature. At higher dyeing temperature, morekinetic energy of dye molecules is responsible for more swelling of fibre and disaggregation of dye molecules which might have resulted into more movement of dye molecules towards the fabric surface and finally penetration inside fibre interstices (Shenai, 1997 and Kamel et al., 2007). Similar trend was observed when cotton fabric was dyed with marigold from $40^{\circ} \mathrm{C}$ to $90^{\circ} \mathrm{C}$ and maximum colour strength was obtained at $90^{\circ} \mathrm{C}$ (Farooq et al., 2013). Similarly silk fabric dyed with eucalyptus leaf extract dye solution exhibited maximum colour strength at 90 ${ }^{\circ} \mathrm{C}$ of dyeing temperature (Mongkholrattanasit et al., 2011). Bouzidi et al., 2016 also found that increase in dye bath temperature resulted in rise in colour strength reaching highest at $100^{\circ} \mathrm{C}$. It was may be attributed to the aptitude of dye migration and aggregation into the fiber which reveals higher $\mathrm{K} / \mathrm{S}$ at this temperature. Generally, this increase of dyeability can be explained by fiber swelling and hence, enhanced dye diffusion (Kamel et al., 2005). Table 7 shows the colour strength and washing fastness of fabric samples dyed for different time durations ranging from 30 minutes to 90 minutes. It can be inferred from Table 7 that increase in dyeing time showed positive correlation with colour strength and wash fastness. With increase in dyeing time from 30 to 90 minutes, colour strength also increased from 3.30 to 4.78 in case of dyed silk fabric samples. Washing fastness also ranged from good (3) to very good (4) in dyed fabric samples. Considering the effect of dyeing time on colour strength and washing fastness, 90 minutes of dyeing time was chosen as optimum for dyeing of silk fabric samples. Table 8 shows the undyed silk 
sample and silk sample dyed using optimized parameters. The dyeability of silk fabric could be attributed to the presence of polypeptide chain which contained many active sites to bind with natural dye through different bondings like covalent, hydrogen bonding, hydrophobic interaction (Yusuf et al. 2016). Kumar et al. (2015) extracted dye from $G$. diversifolia roots and dyed pashmina shawl with and without using synthetic mordants. The higher depth of shade was attributed to the presence of quinine and $8-9 \%$ tannin content in roots.

\section{Conclusion}

The findings of the present study state that $G$. diversifolia dye material extracted in neutral medium at $100^{\circ} \mathrm{C}$ for 90 minutes resulted in higher colour strength and wash fastness ratings. Further

\section{References}

Ammayappan, L. 2009. Application of natural colours on woolen materials. Wool Technology.

Bird, C. L. 1989. Theory and practices of wool dyeing, $4^{\text {th }}$ edition Society of Dyes and Colorists. 111.

BIS. 1979.IS 3361:1979. R2003. Method for determination of colour fastness of textile materials to washing: Test 2.

Bouzidi, A., Baaka, N., Salem, N., Mhenni, M. F., Mighri, Z. 2016. Limoniastrummonopetalum stems as a new source of natural colorant for dyeing wool fabrics. Fibers and Polymers, 17(8):1256-1261.

Farooq, A., Ali, S.; Abbas, N. and Ashraf, M. 2013. Optimization of extraction and dyeing parameters for natural dyeing of cotton fabric using marigold (Tageteserecta). Asian Journal of Chemistry, 25(11):5955-5959.

Gulrajani, M. L. 1999. Present Status of Natural Dyes. In: Convention of natural dyes. 9th - 11th December, 1999. Department of Textile Technology. IIT. Delhi, Replica Production. 3-22.

Kamel, M. M., El-Shishtawy, R. M.,Yussef, B.M. and Mashaly, H. 2005.Ultrasonic assisted dyeing III. Dyeing of wool with lac as a natural dye. Dyes and Pigments, 65: 103-110.

Kamel, M.M., El-Shishtawy, R. M., Youssef, B. M. and Mashaly, M. H. 2007. Ultrasonic assisted dyeing. IV. dyeing of cationised cotton with lac natural dye. Dyes and Pigments, 73: 279-284. dyeing of silk using optimized extraction parameters of dye powder at the rate of $3 \mathrm{gm}$ per $100 \mathrm{ml}$, dyed at $90^{\circ} \mathrm{C}$ for 90 minutes produced higher depth of shade and enhanced wash fastness.

It can be concluded that selection of standard parameters of extraction and dyeing are important to yield better dye ability in terms of colour strength and wash fastness. These optimized parameters can be utilized by small scale dyers, craftpersons, NGOs, etc to dye silk fabric to obtain the dyed textile of better quality. This study provides a new usage to Himalayan nettle plant which can help in generating a new source of livelihood to local people of higher altitude. The farmers can engage themselves in collection, processing and supplying of dye material to textile dyers.

Karim, S. A., Shakyawar, D. B. and Joshi, A. (Eds.). Agrotech Publishing Academy, Udaipur, India, 336-348.

Kumar, A., Raja, A. S. M., Shakyawar, D. B., Pareek, P. K., Krofa, D. 2015. Efficacy of natural dye from Gerardiana diversifolia on pashmina (Cashmere) shawls. Indian Journal of Fibre \& Textile Research, 40(6):180-183.

Misra, S.,Dhyani, D. and Maikhuri, R. K.2010. Wild edible leaves: A study of their subsistence dietetic support to the inhabitants in Nanda Devi biosphere reserve, Uttaranchal. downloaded from http://lyonia.org/articles/deep_dsmile/article_498/pdf/articl e.pdf.

Mongkholrattanasit, R., Kryštůfek, J., Wiener, J. and Viková , M. 2011. Dyeing, fastness, and UV protection properties of silk and wool fabrics dyed with Eucalyptus leaf extract by the exhaustion process. Fibres \& textiles in Eastern Europe, 19(3):94-99.

Mukherjee, S. and Karajan, S. K., 2017. Extraction, optimisation and dyeing of silk yarn using natural dye from cosmos sp. International Journal of Development Research, 7(07):13865-13871.

Nagia, F.A. and Mohamedy R. S. R. 2006. Dyeing of wool with natural anthraquinone dyes from Fusariumoxysporum. Dyes and Pigment, 75:550-555.

Shenai, V. A. 1997. Technology of textile processing (2nd ed.). Mumbai: Sevak publications. pp-159-193.

Swamy, V. N., Gowda, K. N. N. and Sudhakar, R. 2016. Extraction and dyeing conditions of natural dye from flowers of Plumeriarubra $L$. on textiles and fastness 
Standardization and Utilization of Himalayan nettle

properties. Indian Journal of Traditional Knowledge, 15(2):278-284.

Vidhya, R. and Gowda K. N. 2017. Fastness Properties of Silk Fabric Dyed with Extraction of Psoralea Corylifolia (L). International Journal on Textile Engineering and Processes, 3(3): 9

Yusuf, M., Mohammad, F. and Shabbir, M. 2017.Eco-friendly and effective dyeing of wool with anthraquinone colorants extracted from Rubiacordifolia roots: Optimization, colorimetric and fastness assay. Journal of King Saud University - Science, 29: 137-144.

Yusuf, M., Mohammad, F., Shabbir, M.and Khan, M. A. 2016. Eco-dyeing of wool with Rubia cordifolia root extract: Assessment of the effect of Acacia catechu as biomordant on color and fastness properties. Textiles and Clothing Sustainability, 2(10):1-9 